\title{
Award-winning paper in 2015
}

Papers published in Water Management are eligible for awards from the Institution of Civil Engineers. Papers from any of the ICE journals can be nominated for several awards. In addition, each journal has awards dedicated to their specific subject area.

On Friday 7 October 2016, ICE president John Armitt presented an award to the following paper published in Water Management in 2015. The editorial panel nominated their best papers and an awards committee chaired by Nigel Wright allocated the awards.

\section{Robert Alfred Carr Prize}

The Robert Alfred Carr Prize, presented for the best paper published in Water Management, was awarded to Woods (2015).

\footnotetext{
Abstract

In the UK, a disparity exists between modelled future weather/climatic patterns and the assessment of climate change impact on flood risk in the UK statutory planning process. Specifically, the impacts of climate change on the physical characteristics of a river catchment (e.g. land-use change, vegetation cover, soil moisture) are not considered when generating
}

climate change weighted design flood events to assess the potential impact of flooding on a development in the future. Instead, a UK-wide averaged perturbation factor is applied. In this paper, a method is tested to integrate climate change data from UK climate projections 2009 (UKCP09) into design flood estimation methods (ReFH) as part of the current planning process. Scenarios are developed for a single, critical duration, $1 \%$ probability (1-in-100 year) design flood event that reflects plausible changes in catchment physical parameters in the 2080s. Initial results suggest that a 1 -in-100 year storm in the 2080 s may be greater in magnitude, rise and recede faster, and be associated with greater depths of flooding than predicted using current flood risk assessment frameworks in the UK. This information could provide new information to help developers choose more sustainable, flood-resistant and resilient designs.

\section{REFERENCE}

Woods A (2015) Using climate change projections in UK flood risk assessment. Proceedings of the Institution of Civil Engineers Water Management 168(4): 162-173, http://dx.doi.org/10.1680/ wama.12.00064. 